\title{
LIDERANÇAS INTERMEDIÁRIAS NO PROCESSO DE IMPLANTAÇÃO DE ENDOMARKETING
}

\author{
Miguel Luiz Marun Pinto \\ Geraldo da Silva Rodrigues Filho
}

\section{RESUMO}

O cenário atual nos mostra um caminho bem diferente onde os funcionários e as empresas devem caminhar juntos se quiserem sobreviver à nova realidade mundial, onde a globalização trouxe uma incerteza: Como será a organização do futuro? Empresa e funcionário devem, então, entender melhor essa relação e se unirem para aumentar as possibilidades de mercado, bem como aumentar as ofertas de emprego. 0 presente trabalho busca estudar as relações existentes entre a implementação de um programa de Endomarketing e os impactos produzidos por essa atividade nas lideranças de uma organização, ou seja, o estudo irá apresentar a importância das gerências de nível intermediário nos processos de desenvolvimento de um plano de Endomarketing.

Palavras-chaves: Endomarketing. Motivação. Liderança.

\begin{abstract}
The current scenario shows us a different path where employees and companies must work together if they want to survive the new world reality where globalization has brought us uncertainties: What is going to be the organization of the future? Company and employee Will be required to better understand this relationship and join forces to increase market possibilities and expand the job supply. This work aims to evaluate the existing correlation between the implementation of an "Endomarketing" program and the impact caused by this activity in the organization leadership; in other words, the research will portrait the importance of the middle management levels in the development process of na "Endomarketing" plan.
\end{abstract}

Key words: Endomarketing. Motivation. Leadership. 


\section{INTRODUÇÃO}

$\mathrm{Na}$ maioria dos casos, as organizações procuram aplicar suas políticas de marketing externo sem a adesão total de seus funcionários que não são engajados nessas ações pela falta de informação adequada. A comunicação interna é falha e o funcionário fica sem saber os objetivos reais da organização. As evidências levam a crer que a falta de um plano de comunicação interna apropriada que aproxime o empregado da empresa com informações relevantes de todo o processo, nos leva a perceber que o empregado precisa de canais de informação precisos e lideranças aplicadas a se doarem de corpo e alma no sentido de manter as bases operacionais motivadas e estimuladas com a cultura da empresa que trabalham.

O objetivo desse trabalho é identificar a relação entre o Endomarketing e o papel das Lideranças em sua implantação, e permitir que haja uma aproximação entre esses dois elementos com o objetivo de contribuir para uma aplicação correta das ferramentas de Endomarketing como estratégia de gestão, visando o funcionário da base operacional que não pode ser considerado apenas uma ferramenta de trabalho, mas uma pessoa que tem sentimentos e é uma das partes mais importante no processo de relação com os clientes externos, sendo ele o principal cartão de visitas de uma organização.

\section{ENDOMARKETING}

Para entendermos o Endomarketing temos que compreender o significado literal da palavra. Segundo Bekin (1995), o sentido está no marketing voltado para dentro da empresa, ou seja, "uma ação interna que está no próprio significado de endo. Aí temos a palavra grega éndom, que significa 'em, para dentro, dentro de'[...]” (pág 4).

O Marketing que é praticado pelas empresas na busca de conhecer melhor o seu cliente externo deve ser também utilizado para conhecer o seu cliente interno. A partir dessa orientação, devemos fazer com que essa abordagem se interiorize de maneira tal que todos os funcionários se sintam parte desse processo, a estrutura de marketing deve compartilhar suas ações internas e externas de maneira organizada e controlada, sincronizando essas duas ações. Esse conceito vai de encontro ao que Bekin (1995) afirma em:

"Um processo cujo foco é alinhar e sincronizar, para implementar e operacionalizar a estrutura organizacional de marketing da empresa ou organização, que visa e depende da ação para o mercado e a sociedade" (pág 47).

Observamos que o Endomarketing vem sendo utilizado como uma alternativa moderna para aumentar o envolvimento e comprometimento dos funcionários através de uma comunicação interna eficaz, utilizando instrumentos e canais eficientes, e dentro desses parâmetros, há um esforço do marketing para que este se volte para dentro da empresa, focado desde a alta direção até a base operacional, com a preocupação de identificar, atender e satisfazer as necessidades daqueles que fazem o dia-a-dia das organizações.

O cliente interno ou o funcionário que trabalha nas organizações é o foco principal do Endomarketing e este deve ter o seu comportamento estudado e avaliado, e dentro desse contexto, o Endomarketing é uma ferramenta de extrema importância nesse processo. 0 principal benefício que se busca é o fortalecimento e construção de relacionamentos, compartilhando os objetivos da empresa e fortalecendo estas relações, inserindo a noção de que todos são clientes de todos dentro da empresa. 


\title{
A Origem do Endomarketing
}

Apesar de ser um assunto novo, o Endomarketing é considerado como uma ação que faz com que os funcionários de uma determinada organização estejam comprometidos e engajados para alcançar um objetivo comum. Uma das autoras que levantou uma hipótese bem pertinente sobre essa origem, Brum (2005), descreve que:

\begin{abstract}
"Lendo sobre os grandes líderes da humanidade, encontrei um nome com o qual jamais havia se deparado: Fillipo Brunelleschi, que, segundo consta, foi um dos primeiros arquitetos do mundo e teve, como desafio, construir a cúpula da catedral de Florença, considerada a expressão da celebração renascentista do poder divino do indivíduo" (pág 27).
\end{abstract}

Segundo Brum (2005, pág.28), a história conta que, em 1418, foi lançada uma concorrência para a escolha de um projeto para a cúpula da catedral de Florença, que fora iniciada em 1296 e permanecia inacabada até então. Em 1420, os maiores arquitetos da época reuniram-se naquela cidade para analisar as propostas, mas quando chegou à vez de Fillipo Brunelleschi explicar suas idéias, eles riram diante do plano altamente polêmico que apresentara. Ele dizia que era impossível erguer a cúpula de outra maneira, a não ser a que ele tinha proposto. Após muitas discussões os planos de Brunelleschi foram aprovados e ele ganhou a concorrência. A partir de então, o material a ser transportado era muito pesado, pois eram pesadas lajes de mármore e havia muita dificuldade para içar e equilibrar a pedra a muitos metros do ar.

Brunelleschi liderava uma força de trabalho de temperamento difícil e isso lhe era muito trabalhoso, e em um mesmo momento, ainda tinha que lutar contra as constantes tentativas dos seus rivais de sabotarem seu trabalho.

Passado o tempo, Brunelleschi ficou doente e almejava terminar sua obra antes de morrer. Tomou algumas decisões como não permitir que seus funcionários descessem para fazer suas refeições, elas eram servidas no próprio local de trabalho para ganhar mais tempo e produtividade.

Conta Brum (2005, pág.29) que, certo dia, um dos operários estava de aniversário, e ele mandou servir vinho para comemorar. No período da tarde desse mesmo dia, os operários trabalharam mais felizes, utilizando sua capacidade criativa e sugerindo formas de tornar o trabalho mais rápido. Brunelleschi passou a servir vinho todos os dias. No começo da Primavera de 1446, a "forma celestial" da cúpula, conforme ele havia imaginado, estava concluída. Brunelleschi morreu dias depois de sua obra ter sido inaugurada.

\section{O CLIENTE INTERNO E SUA SATISFAÇÃO}

Obter resultados positivos no âmbito do relacionamento com o cliente externo é o resultado de se obter do cliente interno uma satisfação plena de todas as suas ações. Desta forma, essa missão constitui tarefa fácil à medida que todos têm suas expectativas, vontades, necessidades e perspectivas distintas. Essa realidade não faz parte somente do ambiente externo às empresas, mas também do ambiente interno, o que também não é novidade.

Seguindo esta lógica, é importante perceber que as pessoas gostam de ser reconhecidas, respeitadas, bem tratadas e inseridas em um contexto social. Para entender e buscar satisfação dos clientes internos é importante lembrar que, com o passar do tempo, as empresas vêm assumindo papel de responsabilidade em prover qualidade de vida às pessoas que fazem parte do quadro de colaboradores. Algumas empresas não param por aí e 
comprometem-se efetivamente com a busca incessante pela transformação do trabalho em momento de prazer.

Cerqueira (2005, pág19) relata que a "auto-estima das pessoas deve ser desenvolvida, sempre que possível, positivamente, evitando-se afetá-la negativamente". Pessoas que não costumam buscar prazer em suas atividades profissionais costumam ter a sensação de que o trabalho que executam é vazio, sendo comum entre aqueles que passam o dia olhando o relógio aguardarem ansiosamente o término do expediente.

A motivação para o trabalho não depende somente de um esforço particular dos funcionários da base operacional. É muito importante que a motivação torne-se uma reação em cadeia. A alta administração deve estar comprometida e motivada com os objetivos da empresa. É de responsabilidade da gerência, disseminar, através de um processo de comunicação linear e objetivo o sentimento de satisfação, prazer e motivação no trabalho, traçando planos de ação e atuando como espelho para os seus funcionários.

Desta maneira é possível que os funcionários vejam em seus gestores diretos ou não, pessoas que acreditam no que fazem e falam a fim de consolidar o comprometimento com a organização. É ingênuo imaginar que seja possível implantar qualquer projeto de marketing interno com sucesso, se não há a crença e participação efetiva daqueles que disseminam a idéia.

Além de todo o processo que envolve a motivação dos funcionários na obtenção de melhores resultados, com base no comprometimento levado pela satisfação com o trabalho, é importante reconhecer publicamente um trabalho bem feito, verificar se o funcionário dispõe dos melhores meios para desempenhar suas atividades, enfatizar a preocupação da empresa com os funcionários e até mesmo recompensá-los através de premiações e ações que elevem sua moral perante a equipe de trabalho.

Com isso, as empresas, de certa forma, tornam o agente premiado um parâmetro de motivação para que outros possam também atingir altos patamares em seus resultados. No processo de satisfação dos funcionários é primordial que não exista espaço para falhas no seu tratamento, ou seja, é fundamental que não haja desatenção com o relacionamento entre pares, que deve ser cordial, sem atritos, ameaças e coações. Qualquer atitude contrária à convivência cordial pode descaracterizar a essência de um programa de marketing interno, comprometendo inclusive a sua credibilidade.

\section{A INFORMAÇÃO COMO MOTIVAÇÃO}

Segundo Brum (1998, pág.27), existem diversas maneiras de se motivar um funcionário e, abaixo, exemplificamos algumas delas:

- Reconhecimento público de um trabalho bem executado;

- Avaliação de desempenho como base para promoção;

- Participação nos lucros; e

- Remuneração de forma competitiva, ou seja, de acordo com o talento de cada um.

Analisando as maneiras acima, podemos observar que algumas das decisões que listamos podem representar custos para a empresa e podem não estar de acordo com suas políticas internas de gerenciamento. Sobre esse ponto vista, podemos dizer que usando os 
procedimentos mais simples podemos motivar os funcionários de outra maneira como os alimentando com informações necessárias para que seu trabalho seja realizado da melhor forma possível. Nesse caso, a motivação torna-se decorrente de procedimentos mais simples, conforme explica Brum (1998):

\begin{abstract}
“...dar aos funcionários as informações necessárias para realização de um bom trabalho, cumprimentá-lo pessoalmente por uma tarefa bem feita, enviar-lhe uma mensagem escrita elogiando o seu desempenho, solicitar suas idéias, mostrando o quanto são importantes para a empresa, envolvê-los nas questões e decisões relacionadas com o seu trabalho e com a sua área de atuação, etc. Tudo que é feito no sentido de uma maior aproximação empresa/funcionário, do programa mais sofisticado à ação mais simples, está inserido no contexto de endomarketing" (págs 28 e 29).
\end{abstract}

Diante dessas diretrizes, observamos que a informação se torna a principal estratégia entre a empresa e seus funcionários, que é o produto da Comunicação e do Marketing Interno, promovendo um perfeito alinhamento dos conceitos para dirimir as dúvidas que ainda existem a esse respeito.

\title{
GERENCIANDO O ENDOMARKETING
}

As mudanças que ocorreram nos últimos 20 anos, nos fazem refletir que a concorrência acirrada entre as organizações trouxe uma nova forma de competitividade onde o foco no cliente externo não está somente em oferecer produtos e serviços que o satisfaçam, mas buscar uma orientação para que o cliente interno seja o foco também de ações de marketing para que este possa passar a imagem que a corporação gostaria que seu cliente visse. Albrecht (1994, pág11) afirma que "se você algum dia esperar obter coisas externamente, primeiro precisa acertar as coisas internamente".

É nesse contexto que surge como diferencial competitivo à necessidade de se gerenciar o Endomarketing que é praticado dentro das organizações, pois os funcionários de uma empresa devem estar convencidos da qualidade dos produtos e serviços que a empresa presta para seus clientes e sua importância nesse processo. Desta forma, o funcionário tornar-se-á um verdadeiro vendedor desses produtos e serviços. Vender a idéia de qualidade de serviços para os colaboradores da organização será importante para que o programa de Endomarketing a ser implantado obtenha êxito. 0 nível de comprometimento do funcionário deve ser amplo, Albrecht (1998) afirma que o sucesso de uma organização é controlado por aqueles que trabalham na linha de frente e o comprometimento requerido desses funcionários é que:

"1. Entendam o objetivo e a necessidade de alcançá-lo; 2. Acreditem no programa e sintam que ele é importante; 3 . Acreditem que tem possibilidade de sucesso; e 4. Sintam que será valioso para eles pessoalmente." (pág.33).

Entender os objetivos do programa de Endomarketing e fazer com que os funcionários se sintam parte do processo e de sua importância, fará com que estes funcionários entendam que o seu sucesso está atrelado ao seu desenvolvimento pessoal.

Nesse momento a comunicação interna é uma maneira bem eficaz de fazer com que este comprometimento seja alcançado da melhor forma possível e ela só é possível quando há um compromisso a nível departamental, onde estão localizadas as gerências e chefias de nível médio que, mais que simples membros de uma camada na pirâmide organizacional, devem ser aqueles que disseminarão o programa como um todo. Gerenciar essa estrutura de 
Endomarketing requer uma participação ativa desse nível, pois é ele que determinará o bom andamento do projeto a ser implantado.

A princípio, deve se ter à consciência que para se iniciar um programa de Endomarketing deve se pensar nos seus funcionários como um mercado, ou seja, fazer com que esses funcionários comprem, literalmente, a idéia de qualidade de produtos e serviços que estarão sendo disponibilizados para seu público externo. Há de se ter à plena certeza que esse público acredita que o foco principal da empresa é o cliente externo, e ninguém melhor que o pessoal de linha de frente para estar engajado nesse processo, pois são eles que vão oferecer a esses clientes a qualidade esperada no atendimento. Albrecht (1980) afirma que:

"Se seus empregados não estão convencidos da qualidade dos serviços prestados por sua empresa e da importância de seus papéis nessa prestação, não há nada na Terra que os torne dispostos a vendê-la para seus clientes." (pág 33)

Usar o Endomarketing como uma estratégia de gestão seria uma forma de se iniciar um processo global envolvendo todas as camadas organizacionais, desde seu planejamento até a sua implantação. Identificar os problemas com que as empresas se deparam no seu cotidiano é tarefa importante e beneficiará todo o processo do plano. Brum (1998,pág.35) fala a respeito desses problemas que afetam uma empresa, como os cenários de mudança, que segundo a autora são muitos e o que quebra uma empresa não é propriamente a mudança, mas a falta de capacidade das pessoas em se adaptar a ela, e o melhor caminho para se vencer esse obstáculo é buscar a sinergia de todo o grupo, equilíbrio na administração para preparar as pessoas para enfrentar as mudanças que ocorrem na sua vida profissional.

Outro ponto importante é permitir que os funcionários se tornem mais comprometidos através de programas e desafios internos. Não basta apenas os funcionários responderem "sim" verbalmente, mas terem uma participação efetiva em todo o processo. A criação de canais oficiais de informação também devem ser levados em consideração, tendo o cuidado de não permitir que se tornem obsoletos, como descreve Brum (1998):

"A comunicação interna existe em qualquer tipo de empresa e pode ser encontrada, muitas vezes, naquela velha circular que não circulou, cujo assunto ninguém ficou sabendo e que, após não ter mais validade, foi parar no mural ao lado da informação do carro que alguém pretende vender" (pág 50).

A informação deve ser bem canalizada numa comunicação clara e objetiva como uma atividade de Endomarketing extremamente confiável. Fazer Endomarketing requer muito mais que fazer com que os funcionários de uma empresa saibam os valores, a missão ou as metas estabelecidas pela organização. Requer um esforço sistemático e integrado dos instrumentos de comunicação interna para que o público interno compre uma mesma idéia ou um mesmo conceito.

\section{O PROGRAMA DE ENDOMARKETING E SEU PLANEJAMENTO}

Segundo Bekin (1995,pág.55), para entendermos que um programa de Endomarketing é eficaz devemos olhar sob a ótica do marketing em relação ao seu público consumidor, visto que os resultados obtidos são a partir do ponto de vista de seu mercado-alvo. E é dentro desse mesmo princípio que se pressupõe o sucesso e a eficácia de um plano de Endomarketing. Nenhum programa dessa natureza pode ser iniciado sem antes sabermos como está o público interno da empresa. 
Deve-se avaliar cuidadosamente o ambiente interno da organização, na qual estão relacionados: sua missão, seus valores, seus objetivos, seus recursos, sua tecnologia e suas tendências. $\mathrm{O}$ ambiente interno é controlado pelos dirigentes da organização, uma vez que ele é o resultado das estratégias que serão definidas pela alta administração das empresas. Dessa forma, durante a análise, quando for percebido um ponto forte, ele deve ser ressaltado ao máximo; e quando for percebido um ponto fraco, a organização deve agir para controlá-lo ou, pelo menos, minimizar seu efeito.

Segundo Kotler (2000,pág.56), a análise SWOT é uma ferramenta de gestão, muito utilizada como parte do planejamento estratégico de uma empresa. É uma forma simples e sistemática de verificar a posição estratégica do empreendimento analisando o ambiente interno através de suas forças e fraquezas, e o ambiente externo através de suas ameaças e oportunidades. 0 ambiente externo está ligado a variáveis não controláveis pelas organizações, como: demografia, economia, tecnologia, cultura, aspectos sociais, forças políticas e naturais, religião etc. Essas variáveis, apesar das organizações não poderem controlá-las, devem ser conhecidas e monitoradas com freqüência, de forma a aproveitar as oportunidades e evitar as ameaças.

Enquanto Bekin (1995) afirma que: "Essa avaliação do ambiente interno traz à tona aqueles mesmos fatores presentes na avaliação estratégica do ambiente externo, conhecidos como SWOT. É, portanto um SWOT interno" (pág 62).

A análise do comportamento interno da empresa como um todo constitui a primeira fase do programa de Endomarketing que será implantado. Nessa fase, devemos conhecer o pensamento dos funcionários em relação ao seu ambiente de trabalho, em relação aos seus colegas, com a função de desvendar os aspectos até então desconhecidos, numa visão real de toda a empresa feita por aqueles que fazem o seu dia-a-dia. Todo plano de Endomarketing com suas estratégias de comunicação interna só poderá obter sucesso se a empresa souber distinguir e identificar as reais necessidades de seus funcionários.

Como no marketing externo, onde a pesquisa é de fundamental importância, no Endomarketing a pesquisa de clima será aquela que irá orientar o plano, pois será ela que orientará toda a criação do programa.

Segundo Brum (1998,pág.53), a pesquisa tem a função de identificar os pontos de ruptura e criar mecanismos para captar o conhecimento emanado do processo em si. 0 estudo ainda mostra que Brum (1998, pág.54) procura pautar a estruturação do plano de Endomarketing em vários tópicos. Após a primeira fase, onde ocorre à pesquisa, temos ainda cinco outras fases, como veremos adiante.

Na segunda fase, a empresa deve ter em mente o que pretende transmitir a seus funcionários, e fundamentada sobre uma meta global é que deve construir todo os seus objetivos de comunicação interna. Brum (1998, pág.55) nos explica que se o trabalho de comunicação interna não estiver alicerçado em uma grande meta, acaba perdendo o foco e tornando-se um festival de mensagens sem conceito, portanto a linguagem e o visual devem fazer com que os funcionários tenham informações necessárias e façam parte do ambiente empresarial.

A terceira fase do plano está na criação de ícones de comunicação interna. Um slogan ou uma marca ou personagem associada ao slogan seriam uma das formas de atrair os funcionários dando ênfase ao indivíduo e ao presente. Segundo Brum (1998, pág.57), deve representar os funcionários de todos os níveis. 0 slogan seria a assinatura de todos os instrumentos visuais a chamada de todos os programas de integração de funcionários. 
O próximo passo, ou seja, a quarta fase, Brum (1998, pág.59) afirma que devemos dividir o público interno em três camadas: direção, liderança intermediária e pessoal de base. Quando se divide o público interno, pretende deixar clara a grande importância das pessoas que estão na base operacional, pois se o cliente é o objetivo maior e quem o atende são aqueles que estão na linha de frente,é nessa camada que se deve dar a importância maior do processo sem esquecer que é da alta direção a responsabilidade de gerar as informações que serão utilizadas no plano e que as chefias intermediárias têm um importante papel no desdobramento dessas informações.

Com essa divisão, ficam evidentes as responsabilidades de cada grupo e, principalmente, o fato de que serão necessários instrumentos específicos para grupos específicos, com o objetivo que as mensagens sejam assimiladas e para que haja a adesão de todos ao programa, principalmente por parte das lideranças intermediárias.

Na quinta fase temos os instrumentos que, como explica Brum (1998, pág.61), são os meios técnicos para repassar as informações e para operacionalizar o processo da comunicação adequando-os ao suporte da empresa e que, durante todo o programa, a mensagem deve ser trabalhada e bem distribuída. E, finalmente, temos o programa de Endomarketing definido que utilizará os melhores meios para integrar e encantar o público interno, sendo que a melhor estratégia é quando o programa é colocado em prática.

Na sexta e última fase, Brum (1998) finaliza dizendo sobre a importância da escolha do momento para o lançamento do programa e que o objetivo é fazer com que os funcionários percebam essa nova energia, como ela mesma diz:

"É preciso, acima de tudo, um engajamento participativo na hora do lançamento. A empresa deve criar mecanismos para que isso aconteça, permitindo a participação de todos ou pelo menos das lideranças naturais existentes entre o público interno" (pág 89).

Essa troca de energias será de grande importância neste momento, pois o plano sairá do papel para ser executado e nessa hora a conscientização será geral e toda empresa estará unida para um objetivo comum.

\section{OS INSTRUMENTOS DE UM PLANO DE ENDOMARKETING}

Existem muitos instrumentos que podem ser utilizados num plano de Endomarketing.

Segundo Brum (1998, pág.85), esses instrumentos, na sua grande maioria, são escritos ou possuem algum apelo visual, visto que o aprendizado se dá na sua maioria, pela visão. Deve-se estabelecer um parâmetro na escolha desses instrumentos, pois cada empresa deve utilizar daquele que melhor atender. Segundo a autora, são eles:

- Manual de vídeo de integração à empresa;

- Material de acompanhamento do programa;

- Manuais técnicos e educativos;

- Revistas de histórias em quadrinhos;

- Jornal Interno; 
- Encarte da área de Recursos Humanos no jornal interno;

- Página ou encarte da Associação de funcionários do jornal interno;

- Jornal de parede;

- Cartazes motivacionais;

- Cartazes informativos;

- Painel do tempo;

- Painéis motivacionais e decorativos;

- Datas festivas e datas de aniversário dos funcionários;

- Canais diretos entre direção e funcionários (Ex: caixa postal, canais e

- cartões, presidente interativo, presidente ao vivo, gesto à vista, encontros

- formais, reuniões-relâmpago e reuniões de liderança compartilhada);

- Vídeos informativos e motivacionais;

- Tele e vídeo conferências;

- Palestras internas;

- Clubes de leitura;

- Grife interna;

- Intervenções teatrais;

- Mensagens virtuais;

- Valorização de funcionários;

- Ambientação;

- Memória;

- Rádio interna;

- Vídeo jornal;

- Correio eletrônico;

- Intranet; e

- TV a cabo.

Brum (1998, pág.90) relata que esses são alguns dos principais instrumentos que podem ser utilizados pelas empresas, de acordo com sua cultura e seu contexto histórico. As idéias sugeridas são para que as empresas tenham a opção do melhor canal e da melhor forma de fazer uma comunicação interna bem elaborada. 
Ao analisar os processos, desde sua origem até a sua implantação, observamos que o fato de se utilizar os melhores instrumentos técnicos para a sua elaboração não nos dá a garantia da eficácia do programa como um todo. Para o sucesso do plano percebemos que a maneira mais coesa de se conseguir sua eficácia é abordar de uma forma mais específica qual a importância das lideranças intermediárias em todo o projeto.

As lideranças intermediárias devem ser valorizadas para garantir que o pessoal da base tenha as melhores condições de trabalho e estejam bem informados. Dentro deste conceito observamos que todos na empresa sairão ganhando e o cliente externo terá suas necessidades identificadas e seus desejos satisfeitos.

\section{AS LIDERANÇAS INTERMEDIÁRIAS}

Para falar sobre liderança precisamos antes falar sobre o líder, pois sabemos que, segundo Brum (2005, pág.92), liderança é a função do líder, e liderança requer uma habilidade pessoal em influenciar as pessoas e fazer com que elas trabalhem com motivação para o bem de uma equipe. Ser um líder é estar à frente dessa equipe e ter a responsabilidade de conduzir, motivar, guiar e instruir tal equipe a atingir seus objetivos e ideais de uma forma bem entusiástica.

Há uma diferença muito grande entre chefiar e liderar e nem sempre um chefe é um líder, bem como aquele que lidera nem sempre ocupa um cargo de chefia. Uma diferença básica entre os dois é que o chefe tem a missão de atingir objetivos, utilizando-se dos recursos humanos e materiais, enquanto que o líder trabalha com as pessoas a fim de motivá-las e encorajá-las a alcançarem os objetivos propostos.

As ordens de um chefe são obedecidas por força da sua posição. A liderança de um líder é reconhecida e seguida voluntariamente, sem imposição. Para ilustrar melhor esse conceito, Hunter (2004), define liderança como: "a habilidade de influenciar pessoas para trabalharem entusiasticamente visando atingir aos objetivos identificados como sendo para o bem comum" (pág 25).

Outro importante atributo que um líder deve ter é o conhecimento necessário para conviver com os mais variados tipos de pessoas para identificar e descobrir em sua equipe os verdadeiros talentos e mantê-los de alguma forma ativos em suas funções, pois se trata de um ativo escasso e muito importante para as organizações.

\section{O Papel das Lideranças no Plano de Endomarketing}

Quando se observa a maneira pelo qual a comunicação interna através de suas informações irá atingir toda a empresa, verificamos que temos duas formas de se fazer à informação fluir do topo para a base da pirâmide através de dois processos: verticalmente e horizontalmente.

No sentido horizontal, seria o caminho que percorre a informação por meio de canais, instrumentos e ações que segundo Brum (2005) "são os meios técnicos para fazer operar o processo da Comunicação Interna” (pág 44). Por esse processo é que a informação é repassada a todos os funcionários da empresa de maneira técnica e operacional.

No sentido vertical, o caminho percorrido pela informação seria por meio das lideranças. Pois ela "possui um papel complementar aos canais, instrumentos e ações" (pág. 44), de acordo com Brum (2005). 
Nesse conceito, podemos analisar que é de responsabilidade das gerências intermediárias a disseminação da cultura organizacional e do desenvolvimento dos valores éticos e morais que vão traduzir todo o processo a ser implantado.

Observamos, abaixo, as figuras das pirâmides, para termos uma idéia mais clara do assunto que estamos abordando, ou seja, os dois caminhos da informação:

Figura 1:

Caminho 1 (Processo Horizontal)

Por meio de canais, instrumentos e ações

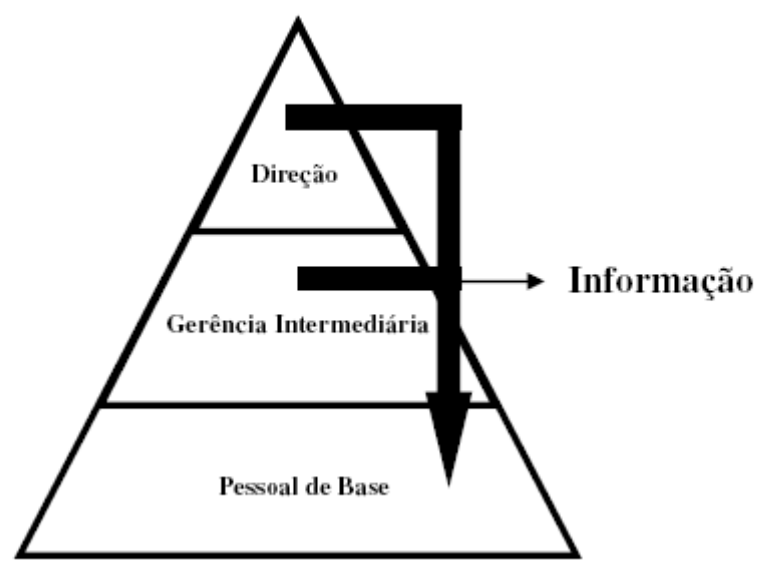

Fonte: BRUM, Analisa de Medeiros. 2005, pág 45

Figura 2:

Caminho 2 (Processo Vertical)

Por meio de lideranças

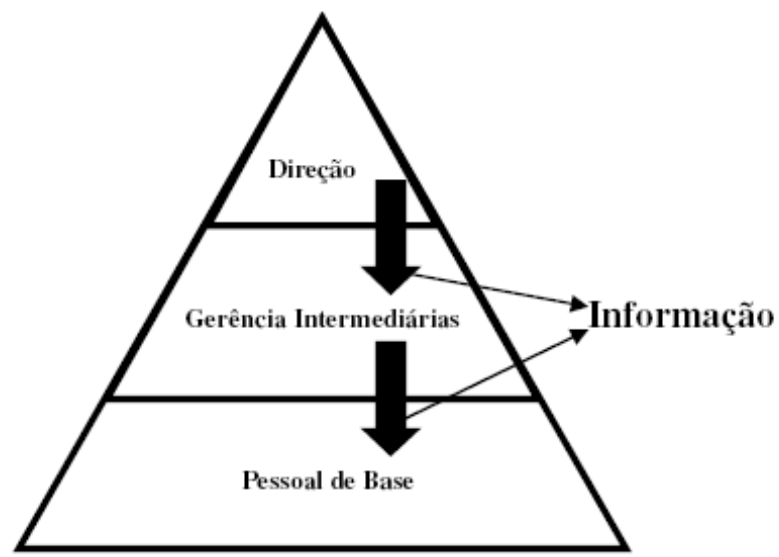

Fonte: BRUM, Analisa de Medeiros. 2005, pág. 45.

As lideranças intermediárias são aquelas que vão desdobrar os planos estratégicos da alta direção e criar opções táticas para que a base operacional possa desenvolver essas ações de maneira coesa e dinâmica.

As lideranças intermediárias são importantes nesse sentido, pois irão agir como os divulgadores das políticas que permeiam a empresa em todos os seus segmentos. São elas que 
vão promover a sinergia entre os departamentos e também são elas que devem ser mais bem preparadas para difundir esses valores.

O pessoal da base operacional deve se sentir incentivado, motivado e parte integrante do processo, sabendo de sua importância para a organização. 0 início para que essas lideranças possam desempenhar um bom papel dentro do processo da informação é um bom treinamento por parte da organização e, posteriormente, serem chamadas como parceiras para a implementação do plano.

\section{O Líder Como Exemplo}

Um líder precisa se tornar um exemplo para seus seguidores e para isso precisa ter um autoconhecimento de sua natureza pessoal e saber dos seus limites. Dentro desse ponto, a sua palavra se torna verdadeira e suas atitudes firmes. Deve ter a consciência de que a única maneira de trocar experiências com as pessoas é através da maneira como se doa nesta relação.

São atitudes simples que, segundo Brum (2005, pág.33), pode ser um exercício diário sem precisar de muito esforço, e como exemplo podemos dizer que se ele quer alegria, ele deve doar alegria, se deseja ser amado, deve aprender a dar amor, e assim por diante.

Outro importante fator para o líder é que tudo que ele fizer vai gerar, de alguma forma, uma resposta, pois segundo Hunter (2004,pág.25), comportamento, gera comportamento. Antes de fazer com que a comunicação chegue aos seus seguidores, ele deve sempre analisar a mensagem como um todo para saber a melhor maneira de informar a sua equipe, de forma que não se sintam constrangidos ou inconfortáveis com o que está sendo transmitido, e nesse ponto a comunicação deve ser clara e adequada ao receptor dessa mensagem.

Um outro atributo do líder é entender e acreditar que nada acontece por acaso e que as leis da natureza estão presentes para ensiná-lo e que não adianta, segundo Brum (2005), "dispensar um esforço sobrenatural para fazer uma comunicação, basta utilizar a melhor forma da sua potencialidade pura e o amor que possui dentro de si”. (págs 103 e 104)

Outro fator importante que o líder precisa entender é que se preparar para influenciar as pessoas requer uma profunda reflexão em todos os planos de sua vida.

Deve o líder ter um perfeito relacionamento com aqueles que estão à sua volta e essa preparação está no autoconhecimento de seus limites e como trabalhá-los no sentido de que as pessoas o vejam como pessoa que é, para depois admirá-lo profissionalmente. Uma das maneiras mais interessantes para que isto aconteça é o desenvolvimento da sua capacidade de saber ouvir atentamente os subordinados para que eles tenham uma plena confiança na sua liderança.

Há pessoas que acreditam que o líder já nasce líder e que é só deixá-lo à vontade que ele vai fazer fluir a sua liderança naturalmente. Outros, porém, crêem que todos nós temos um potencial de liderança que precisa ser desenvolvido e aperfeiçoado. Segundo Hunter (2004, pág.53), as duas posições podem ser consideradas verdadeiras, entretanto, alguns fatos devem ser observados.

Por exemplo, o líder nato, embora esteja livre para fazer fluir a sua liderança, precisa de acompanhamento de pessoas mais maduras que o orientarão no exercício da sua liderança para que, por falhas de caráter principalmente, não venha a se tornar um ditador ou alguém 
em quem não se pode confiar.

Por outro lado, os que não podem ser considerados líderes natos,mas que possuem um potencial de liderança a ser desenvolvido, precisam aprender técnicas de liderança que os ajudarão a desenvolverem seus ministérios com maior eficácia. No entanto, esse último grupo precisa estar consciente de que todas as técnicas de liderança se tornarão inúteis se o líder não possuir uma personalidade firme, ou se possuir uma auto-estima muito fraca. Portanto, maturidade emocional e técnicas de liderança são dois ingredientes essenciais para o líder.

Observamos que os funcionários da base estão muito mais próximos do cliente do que o Presidente da empresa, e eles vão proporcionar aos clientes da organização os "momentos de verdade" e, segundo Hunter (2004), neste modelo "todos estão olhando para cima, para o chefe e longe do cliente". (pág 48)

Figura 3:

\section{VELHO PARADIGMA}

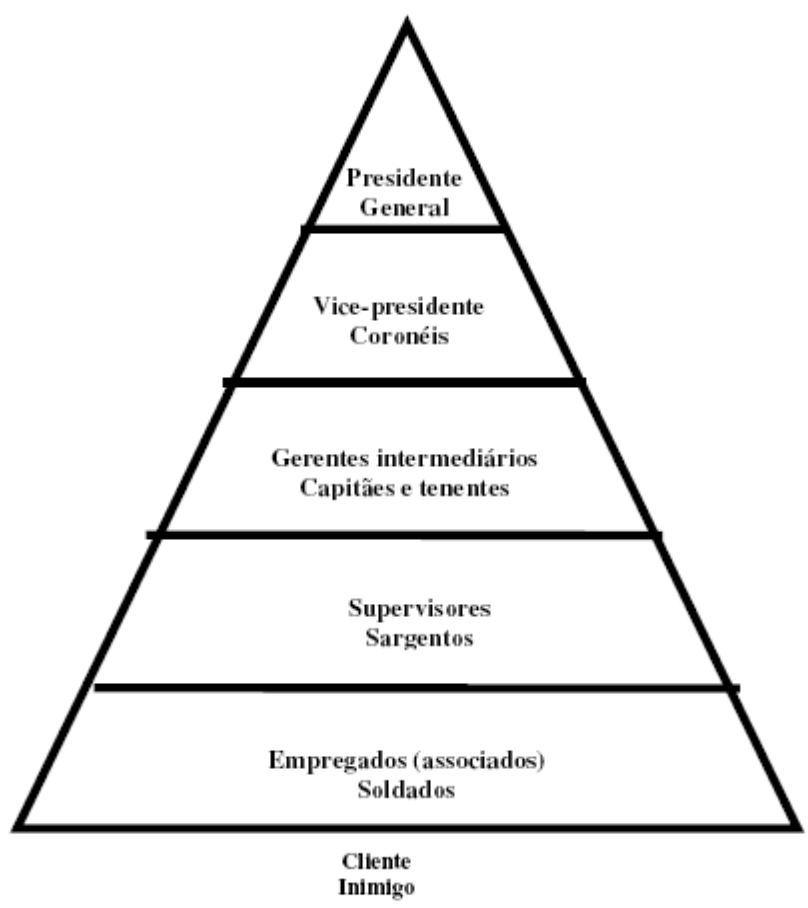

Fonte: HUNTER, James C. 2005, pág. 47.

Observamos que os funcionários da base estão muito mais próximos do cliente do que o Presidente da empresa, e eles vão proporcionar aos clientes da organização os "momentos de verdade" e, segundo Hunter (2004), neste modelo "todos estão olhando para cima, para o chefe e longe do cliente" (pág 48).

Isto significa dizer que as mensagens são enviadas de cima para baixo e que os funcionários de base não trabalham com o foco no cliente e, sim, em seus superiores imediatos, e assim por diante, até chegar ao topo, pois no alto é que está a camada que tem mais valor neste modelo.

Entretanto, se invertermos a pirâmide temos como a parte mais importante do negócio o cliente externo e para ele estará voltada todas a ações, sendo que a camada mais importante 
da pirâmide será, agora, o pessoal de base.

Figura 4:

NOVO PARADIGMA

Cliente

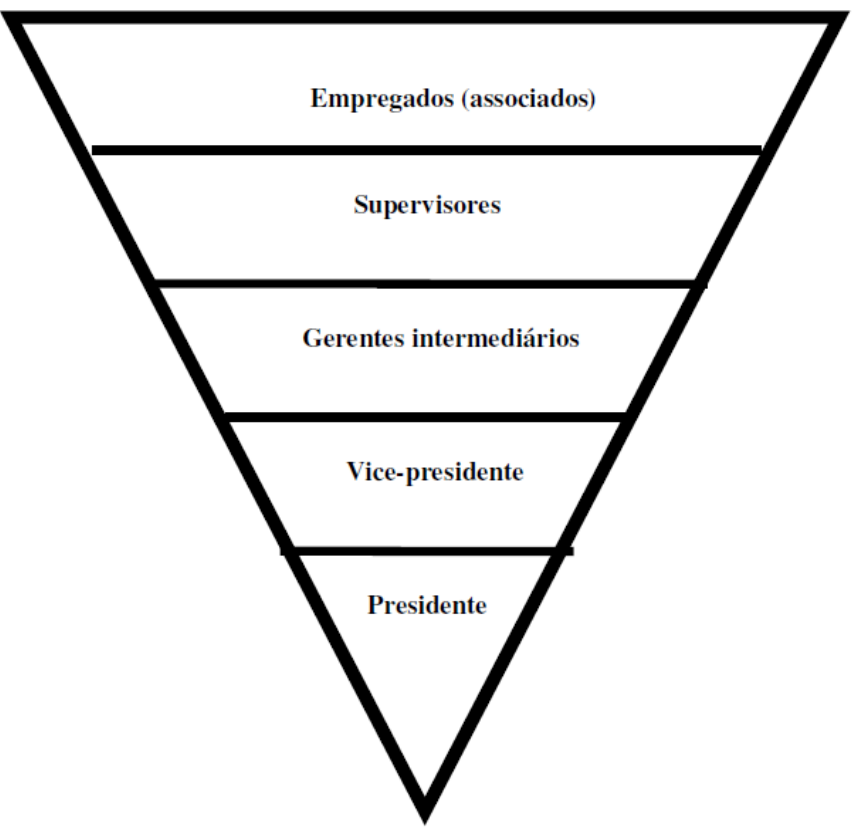

Fonte: HUNTER, James C. 2005, pág 50

Hunter (2004, pág.48), ensina que uma organização deve pensar e ter como objetivo principal servir ao seu cliente externo. Os seus funcionários de linha de frente devem estar servindo e garantindo que as reais necessidades desses clientes estarão sendo satisfeitas. E que também os seus superiores pudessem agir da mesma forma, e assim por diante.

\section{Como o Líder Interage}

Partindo do princípio de Brum (2005, pág.56) que o líder tem seu sucesso influenciado pelo relacionamento de qualidade que possui com sua direção e com suas bases, pois ele se encontra no nível intermediário recebendo e repassando informações, considera-se que o exercício de ter uma atenção maior para com os seus liderados aumenta e intensifica as bases de confiança e respeito.

No processo de comunicação, onde a informação flui de cima para baixo, o líder se torna o receptor dessas informações que são geradas, segundo Brum (2005, pág.58), na parte de cima, ou seja, da alta administração, do topo da pirâmide organizacional. A captação da mensagem é ponto chave para o líder poder desenvolver sua capacidade de compreensão da mensagem e evitar que ela chegue aos seus liderados com ruídos ou distorções. A troca de informações deve ser estabelecida sobre a verdade para que seja gerada em seus liderados uma alta confiança na sua pessoa.

No momento de repassar essas informações para o seu grupo, o líder deve ter em mente que a linguagem que utiliza, principalmente com pessoas que na maioria dos casos têm um nível de cultura mais baixo, pode ser de compreensão geral que vai produzir ações positivas ou mal 
entendidos e frustrações por parte dos funcionários.

Brum (2005, pág.60) relata que existem algumas técnicas que podem ser utilizadas para que a mensagem que o líder envia seja mais clara e objetiva. E essas técnicas, segundo Brum (2005, pág.62), são:

- Usar o feedback, para ter a certeza que a mensagem foi compreendida.

- Uso de canais múltiplos, utilizando métodos diferentes e simultâneos para transmitir a informação.

- Usar os padrões de comunicação das pessoas que compõem a equipe pode ajudar o líder a determinar se elas são receptivas ou não às informações que estão sendo repassadas.

- Prestar atenção nos significados simbólicos, pois às vezes o líder imagina estar enviando um tipo de mensagem, e esta ser recebida de uma maneira totalmente diferente por parte das pessoas.

- Usar uma linguagem simples, ou seja, não usar de palavras difíceis de entendimento.

- Repetir: é uma forma de reforçar a mensagem e dar chances às pessoas de entendê-la.

Outro importante fator é saber como os funcionários gostariam que a informação lhes fossem transmitidas, utilizando os devidos canais para que a mensagem não seja distorcida. Saber ouvir, segundo Brum (2005), é "uma das técnicas de comunicação mais desafiantes. Mas é também uma das mais freqüentemente ignoradas" (pág 124.)

Um relacionamento se sustenta através de uma relação em que saber ouvir é fundamental e o líder precisa entender esse aspecto se quiser que sua equipe tenha uma interação consigo e com o que será estabelecido no plano de comunicação que vai utilizar em seu dia-a-dia, criando um ambiente em que seja possível o diálogo aberto e sincero por parte dos integrantes de seu grupo.

\section{Como o Líder enfrenta as Mudanças}

Estamos numa era em que as mudanças ocorrem com rapidez extrema e no mundo corporativo não é diferente. Saber entender essas mudanças e estar atento às novas demandas, requer do líder uma capacidade de administrar essas mudanças, tornando-as mais amenas na vida das pessoas com quem trabalha. Segundo Brum (2005):

"Quando um líder não gerencia a mudança de forma satisfatória e baseada na informação, seus subordinados certamente ficam na defensiva, montando aquilo que chamamos de "barricadas" e fazendo com que os processos demorem mais do que deviam" (pág 132)

Na comunicação do líder está a capacidade de transformar os desafios em oportunidades de encorajar a sua equipe e entusiasmá-la cada vez mais para que possam ter a visão de que as mudanças são desafios interessantes e não ameaças ou motivos de estresse.

O líder precisa saber que para mudar um determinado comportamento, individual ou coletivo, ele deve usar da técnica de repetir várias vezes o mesmo assunto, treinar a pessoa ou o grupo e pôr em prática o novo comportamento que deseja em seu liderado. A posição do líder é muito importante nesse aspecto de mudanças de cenário, pois é ele que, com seu 
comportamento, vai ajudar o grupo a superar os obstáculos impostos para alcançar os melhores objetivos. Cabe ao líder ajudar a controlar o estresse no local de trabalho com o intuito de auxiliar nos momentos de transição, proporcionando à equipe oportunidades de relaxamento e recuperação do seu equilíbrio normal.

\section{O MODELO DE LIDERANÇA}

Para implantar um plano de Endomarketing, dispomos de meios técnicos e acadêmicos para que ele seja executado da melhor forma possível. Entretanto, executá-lo de maneira produtiva, requer da liderança um engajamento para que todo o processo seja satisfatório, e principalmente, um comprometimento maior que os demais, porque ela será a ligação entre a alta administração e a base da empresa.

Os líderes, nesse processo, devem ter em mente a importância que têm nesse contexto e optar por um modelo de liderança que Hunter (2004, pág.65) chama de liderança a serviço, que significa que o líder se quiser obter êxito, deve despojar de sua condição de poder que possui e agir a serviço de seus liderados. Com essas atitudes, o líder será respeitado por sua autoridade, porque o seu comportamento vai gerar uma equipe mais coesa e determinada a atingir as metas globais da organização.

Hunter (2004, pág.66) nos mostra que o modelo de liderança baseado na autoridade, serviço, sacrifício, amor e vontade constituem uma bússola para os líderes modernos, que, como Fillipo Brunelleschi, há muitos anos atrás, já utilizava empiricamente com seus empregados.

\section{CONCLUSÕES}

Baseado nos objetivos do presente estudo e tomando como referência a importância que as lideranças possuem no cenário atual, apresentam-se as conclusões que se seguem. As empresas apresentam políticas de relacionamento com seus clientes externos e por muitos anos ignorou uma realidade que faz parte do seu dia-a-dia: a maioria deles é atendida pelo pessoal de base.

Parte dessa ignorância deve-se ao fato de um pensamento orientado somente para a venda e não na construção de relacionamentos longos e duradouros para reter o seu cliente e fazer com que ele volte a sua loja para comprar novamente. Muitas dessas empresas ainda acreditam que o cliente não tem muitas opções de compra e por oferecerem produtos de alta qualidade, fundamentam suas estratégias no produto.

O Endomarketing aparece como um dos melhores provedores do sucesso empresarial, a partir do momento que a empresa começa a se preocupar como ela estará posicionada num futuro próximo. As organizações nos dias atuais estão passando por profundas transformações na maneira de agir e pensar, devido ao fato da concorrência acirrada e de tantas mudanças que ocorrem no âmbito externo da organização. Desenvolver suas lideranças é o ponto chave desse estudo para que as empresas consigam transformar o seu plano de Endomarketing numa ação que vai transformar suas relações com o seu cliente externo em algo que trará benefícios significativos para toda a organização.

O estudo demonstrou que as lideranças devem ter um conjunto de valores que fará com que aqueles que são seus liderados trabalhem com mais prazer e estejam realmente comprometidos com a história, os valores e a missão da empresa em que trabalham, influenciados positivamente por seus líderes, e para isso é preciso uma entrega total à causa, uma mudança de comportamento e a adoção de um modelo de liderança baseado na 
autoridade, no serviço, no sacrifício, no amor e na vontade.

Nesse ponto de vista, entendemos que o trabalho deve ser visto com prazer pelo líder que o executa, e não somente por vaidade pelo que a empresa representa no mercado, o reflexo dessa entrega será a maneira pela qual os resultados positivos serão alcançados.

Para as organizações, a certeza da manutenção de sua posição no mercado e a perspectiva de abertura de novos mercados, a expansão física do seu negócio e um maior investimento em novos produtos e de serviços.

\section{BIBLIOGRAFIA}

ALBRECHT, Karl. Serviços Internos: Como Resolver a Crise de Liderança do Gerenciamento de Nível Médio. São Paulo: Pioneira, 1994.

BEKIN, Samuel Faingauss. Endomarketing: Como Praticá-lo Com Sucesso. São Paulo: Prentice Hall, 1995.

BRUM, Analisa de Medeiros. Endomarketing como estratégia de gestão: Encante seu Cliente Interno. Porto Alegre: L\&PM, 1998.

BRUM, Analisa de Medeiros. Face a face com o endomarketing: o papel estratégico das lideranças no processo das informações. Porto Alegre: L\&PM, 2005.

CERQUEIRA, Wilson. Endomarketing: Educação e Cultura para a Qualidade. Rio de Janeiro: Qualitymark, 2005.

CUSINS, Peter. Gerente de Sucesso: Liderança e Eficácia. São Paulo: Clio, 1994.

HUNTER, James C. O Monge e o Executivo. [tradução Maria da Conceição Fornos de Magalhães]. Rio de Janeiro: Sextante, 2004.

KOTLER, Philip e ARMSTRONG, Gary. Princípios de Marketing. Rio de Janeiro: Prentice Hall, 1998.

KOTLER, Philip. Administração de Marketing: A Edição do Novo Milênio. São Paulo: Prentice Hall, 2000. 